\title{
PROGRAM PEMBERDAYAAN MASYARAKAT PENGUSAHA RAMUAN HERBAL DI KELURAHAN GADEL KECAMATAN TANDES KOTA SURABAYA
}

\author{
Erwan Aristyanto, Yuli Ermawati, Aditya Surya Nanda \\ erwanaristyanto@uwp.ac.id \\ Fakultas Ekonomi dan Bisnis \\ Universitas Wijaya Putra \\ Jl. Raya Benowo 1-3 Surabaya \\ Indonesia
}

\begin{abstract}
Abstrak
Ditengah merebaknya Covid - 19 atau virus Corona berbagai produk herbal laris manis di pasaran tak terkecuali produk UMKM minuman ramuan herbal tradisional ikut terdongkrak. Momentum ini harus di manfaat sebaik mungkin oleh pelaku usaha. Mitra kami adalah Ibu Sunarti yang lebih dikenal dengan panggilan Bu Yanto, berdomisili di Kelurahan Gadel, Kecamatan Tandes, Kota Surabaya. Beliau menitipkan ramuan herbalnya di toko - toko kelontong sekitar yang memiliki lemari pendingin. Karena keterbatasan ramuan herbal yang hanya menjual produk sinom, keterbatasan administrasi pembukuan, keterbatasan IPTEK dan permodalan membuat ibu Sunarti tidak berani memperluas pasar. Padahal semangat dan potensi produk ramuan herbal sangat menjanjikan. Solusi yang di berikan yang pertama yaitu dengan melakukan uji coba penambahan varian produk. Kedua, memberikan pendampingan dan pelatihan manajemen keuangan dan usaha, Ketiga, memberikan pendampingan dan pelatihan manajemen pemasaran, baik secara offline ( pelabelan, brosur, kartu nama dan konsinyasi ) maupun online ( sosial media, marketplace ) untuk meningkatkan jangkauan pasar. Metode yang di gunakan adalah pendampingan personal terhadap mitra. Rencana yang akan dilakukan oleh tim adalah dengan memberikan pelatihan untuk manajemen usaha mereka ( mulai dari proses pengelolaan produksi, pembukuan sederhana, pemasaran efektif dan inspirasi penegusaha sukses ) dengan mendatangkan para pakar yang kompeten untuk mendongkrak usaha mereka. Setelah itu tim akan mengawal mitra untuk membuat label yang modern dan menarik dengan merek yang mereka ciptakan. Kemudian mendampingi mitra dalam memasarkan produk secara offline dan online agar jangkauan pasar lebih luas. Dengan begitu diharapkan pendapatan dan kesejahteraan mitra akan meningkat.
\end{abstract}

Kata Kunci : Imunitas, Ramuan Herbal, Sinom, UMKM

Ekonomi, Sosial, dan Budaya 


\section{PENDAHULUAN}

\section{Analisis Situasi}

Islam adalah agama Rahmatan Lil Alamin, sebagai petunjuk bagi seluruh sisi alam, termasuk memberikan perhatian yang sangat besar pada dasar - dasar umum pengobatan dan kesehatan. Salah satunya adalah firman Allah SWT dalam separuh Surat Al A'raf ayat 31 yang artinya ; "Makan dan minumlah dan jangan berlebih lebihan”. Menurut Ibnu Qayyim al - Jauziyah dalam ayat ini Allah SWT memberikan petunjuk kepada hambanya untuk memasukkan materi yang dapat memperkuat ketahanan tubuhnya, seperti makanan, minuman dan sejenisnya sebagai ganti dari materi - materi yang di urai oleh tubuh. Akhir tahun 2019 dunia digemparkan dengan munculnya wabah penyakit yang pertama terjadi di kota Wuhan China, wabah ini muncul disebabkan karena Virus Corona atau severe acute respiratory syndrome coronavirus 2 (SARS$\mathrm{CoV}$-2)merupakan jenis baru dari virus Sars, disebabkan karena kebiasaan buruk dari penduduk Wuhan yang gemar mengkonsumsi daging hewan liar, selang beberapa bulan kemudian virus ini menyebar ke berbagai negara diseluruh dunia, tak terkecuali Indoensia juga ikut terpengaruh dari dampak terjadinya virus ini, virus yang menyerang anggota penafasan atas ini, berdampak sangat fatal karena dapat menular ke manusia, bahkan bisa terjadi kematian, dengan tingkat penyebaran yang sangat cepat, dibutuhkan kekuatan imuntas dalam tubuh sehingga bisa tahan terhadap serangan virus Covid19 tengah merebaknya Covid - 19 atau virus Corona berbagai produk herbal laris manis di pasaran tak terkecuali produk UMKM minuman jamu tradisional ikut terdongkrak. Momentum ini harus di manfaat sebaik mungkin oleh pelaku usaha. Sebagai kelompok usaha kecil, UMKM selalu terjebak dalam problem keterbatasan modal, teknik produksi, pemasaran, manajemen dan teknologi. Sebagai upaya untuk meningkatkan kemampuan usaha kecil dalam rangka memperluas perananya didalam perekonomian nasional, diperlukan serangkaian pembinaan terpadu dan berkelanjutan untuk mengatasi berbagai masalah tersebut terutama bersumber pada masalah keterbatasan pengetahuan, informasi dan permodalan.

Ramuan herbal adalah produk minuman tradisional seperti sinom, beras kencur, temulawak dll terbuat dari jahe, kunyit, asam jawa, temulawak, kapulaga, dan rempah - rempah lainnya. Ramuan herbal merupakan minuman kesehatan alami yang banyak memberikan manfaat bagi tubuh antara lain : menurunkan berat badan,membantu perkembangan otot dan syaraf, melawan kanker, meningkatkan imunitas, dll.

Mitra program pemberdayaan masyarakat (PPM) adalah pengusaha ramuan herbal (sinom, beras kencur, rempah - rempah). Mitra kami bernama Ibu Sunarti yang lebih dikenal dengan panggilan $\mathrm{Bu}$ Yanto. Beliau adalah ibu rumah tangga dengan 4 orang anak bertempat tinggal di Gadel Sari Madya 1B no 15 Kelurahan Gadel, Kecamatan Tandes, Kota Surabaya. Pengetahuan Beliau berdagang minuman ramuan herbal didapatkan dari secara otodidak karena keterbatasan ekonomi untuk membantu keuangan keluarga. Selama 2 tahun Beliau mampu bertahan menghadapi persaingan, dan menyebabkan beliau memiliki banyak pelanggan tetap.

\section{Identifikasi dan Perumusan Masalah}

Proses produksi ramuan herbal milik $\mathrm{Bu}$ Sunarti juga masih tergolong konvensional. Bahan - bahan yang beliau gunakan adalah daun asam yang masih muda ( sinom ), buah asam jawa, kunyit ( kupas kulitnya dan haluskan ), temulawak ( kupas kulitnya dan haluskan ), lada, kapulaga, kayu manis, gula merah ( sisir halus ), gula pasir, garam halus dan air secukupnya. Langkah langkah dalam proses produksi adalah membersihkan daun asam dari tulangnya, setelah itu cuci bersih semua bahan dengan air dan rebus

$$
\text { Ekonomi, Sosial, dan Budaya }
$$


semua bahan sampai benar - benar mendidih dan matang matikan kompor kemudian tunggu hingga dingin minuman sinom dan saring agar endapan tidak ikut di masukkan ke dalam botol. Beliau menjajakan ramuan herbal dengan cara berkeliling di wilayah sekitar Balongsaridengan membawa sepeda motor. Beliau menitipkan ramuan herbalnya di kantin - kantin Sekolah, Sentra Kuliner serta toko - toko kelontong sekitar yang memiliki lemari pendingin. Berdasarkan uraian diatas maka tim pelaksana pengabdian ini membuat kesimpulan bahwa permasalahan mitra adalah :

1. Pengetahuan mitra dalam bidang produksi pengolahan minuman ramuan herbal belum cukup baik sehingga kualitas produk belum standar.

2. Terbatasnya pengetahuan dan skill mitra dalam bidang pemasaran membuat pesimis untuk melakukan penjualan kepada pasar yang lebih luas.

\section{Tujuan Kegiatan}

1. Membantu mitra dalam pengolahan produksi dan pemasaran ramuan herbal sehingga dapat meningkatkan kesejahteraan keluarga melalui peningkatan penghasilan.

2. Meningkatkan kualitas hidup keluarga melalui pemanfaatan sumberdaya alam dan sumberdaya manusia.

\section{Manfaat Kegiatan}

Manfaat kegiatan dalam program pengabdian masyarakat ini adalah tim pengabdian bersama - sama dengan mitra dengan mencoba menyelesaikan permasalahan yang di hadapi mitra yaitu :

1. Meningkatkan pengetahuan mitra dalam bidang produksi ramuan herbal sehingga dapat memproduksi ramuan herbal dengan variasi lebih banyak dan produknya lebih berkualitas.

2. Meningkatkan pengetahuan mitra dalam bidang administrasi dan keuangan

3. Meningkatkan pengetahuan dan keahlian mitra dalam bidang pemasaran sehingga dapat memasarkan produk lebih luas.

\section{MATERI DAN METODE PELAKSANAAN}

\section{Solusi}

Dalam upaya meningkatkan nilai tambah dan memecahkann permasalahan yang di hadapi mitra, maka solusi yang ditawarkan adalah sebagai berikut :

1. Memberikan pelatihan bidang produksi ramuan herbal sehingga dapat menambah variasi produk yang di hasilkan.

2. Memberikan pelatihan dan pendampingan administrasi keuangan untuk penentuan harga pokok produksi.

3. Memberikan pelatihan dan pendampingan tentang manajemen pemasaran, sehingga mitra mampu menyusun rencana strategi pasar yang lebih luas.

\section{Metode Kegiatan}

1. Pelatihan pembuatan produk dengan variasi yang lebih banyak, hygienis dan tahan lebih lama.

2. Pelatihan dan pendampingan administrasi keuangan sederhana

3. Pelatihan dan pendampingan pemasaran produk sesuai pasar.

Metode pengembangan mitra pengusaha ramuan herbal di Kelurahan Gadel Kecamatan Tandes Kota Surabaya menggunakan metode pemberdayaan potensi mitra dan potensi situasi pandemi Covid - 19 yang sedang berlangsung.

\section{Rancangan Evaluasi}

Metode evaluasi dilakukan dengan cara evaluasi program pelatihan di lakukan wawancara dengan konsumen tentang preferensi konsumen terhadap rasa, kemasan, harga dan kemasan produk.

\section{HASIL DAN PEMBAHASAN}

\section{Gambaran Umum Usaha}

Berdasarkan metode pelaksanaan kegiatan yang di tawarkan tim pengabdian masyarakat tentang manajemen usaha, maka dari mitra Pedagang Ramuan Herbal di Kelurahan

$$
\text { Ekonomi, Sosial, dan Budaya }
$$


Gadel Kecamatan Tandes Kota Surabaya di beri nama "Ibu Yanto " karena yang menjalankan usaha adalah ibu Sunarti yang merupakan istri dari Pak Yanto, yang lebih di kenal oleh masyarakat sekitar. Awalnya usaha ini hanya memproduksi sinom, namun sesuai perkembangan dari pelatihan tim pengabdian masyarakat maka sekarang usaha ini telah memiliki jenis produk yang lebih bervariasi yaitu beras kencur dan rempah - rempah. Pedagang Ramuan Herbal di Kelurahan Gadel Kecamatan Tandes Kota Surabaya di bernama "Ibu Yanto" ini juga sudah memperoleh Surat Izin Usaha Perdagangan dengan NO SIUP : 503/10620.A/436.7.17/2018.

Sesuai dengan teori siklus hidup produksi (Product Life Cycle), usaha pembuatan ramuan herbal ini masih taraf pengenalan produk (Heizer\&Render,2006,200). Variasi produk yang sedang mencari pasar sasaran. Sebenarnya masalah kualitas produk sudah baik dan mampu bersaing dengan produk sejenis namun masih perlu di lakukan standartisasi lagi. Harga jual juga perlu di tentukan, karena belum ada catatan yang baik sehingga harga kadang berubah - ubah.

Serangkaian aktivitas yang menghasilkan nilai dalam bentuk barang dan jasa dengan merubah input menjadi output dengan kegiatan yang terencana dengan berbagai strategi yang di perlukan(Heizer\&Render,2006:4). Berdasarkan teori ini maka PPM Pedagang Ramuan Herbal Pedagang Ramuan Herbal di Kelurahan Gadel Kecamatan Tandes Kota Surabaya di perlukan bebrapa strategi dan program dalam bidang bidang manajemen yang meliputi : organisasi, produk, administrasi, pemasaran dan keuangan yang hasilnya akan di urai lebih lanjut.

\section{Produksi}

Jenis produksi usaha Pedagang Ramuan Herbal di Kelurahan Gadel Kecamatan Tandes Kota Surabaya sudah mulai bervariasi, sebelum pelatihan dan pendampingan hanya menjual sinom saja, namun sekarang sudah memiliki tambahan dua varian produk yaitu beras kencur dan rempah - rempah. Untuk sinom, beras kencur dan rempah - rempah di produksi dalam kemasan botol $500 \mathrm{ml}$ dengan harga jual di buat sama semua yaitu sebesar Ro.5000,- per botol.

Bahan dasar pembutan minuman ramuan herbal ini menggunakan bahan alami yang diperoleh dengan membeli di pasar - pasar tradisional, Jenis bahan bakunya terdiri dari berbagai jenis yaitu jenis rimpang seperti kencur, temulawak, kunyit, jahe dan sejenisnya. Jenis bahan lainnya berupa kayu - kayuan seperti kayu manis, kayu secang. Jenis yang lain berupa bijibijian seperti kedawung, ketumbar, merica, biji saga. Disamping itu juga menggunakan buah dan daun asam jawa. Selainbahan dasar tersebut juga di tambahkan gula jawa (gula merah) dan air. Berikut tahapan pemprosesan minuman ramuan herbal ibu Yanto.

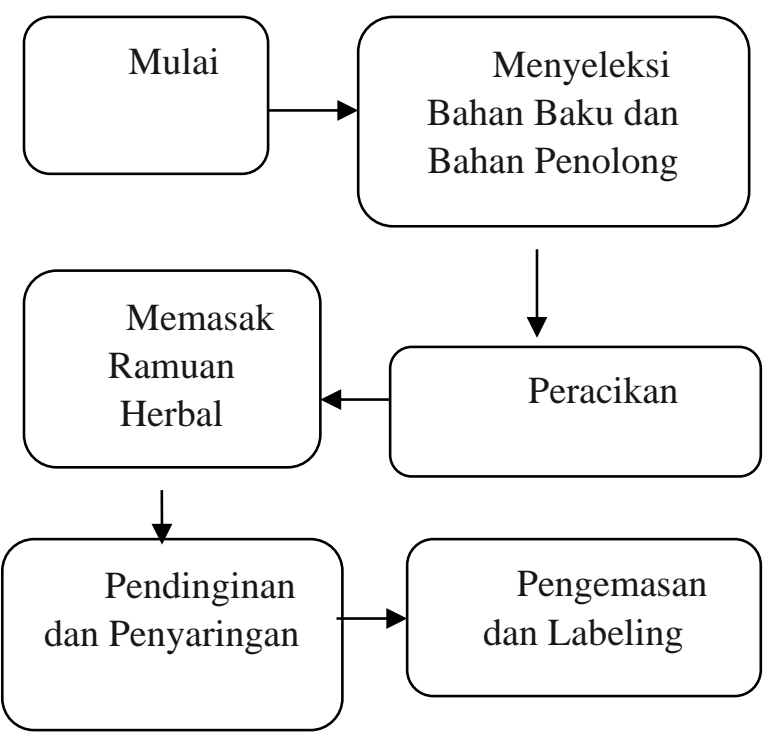

Diagram 1. Tahapan Pemprosesan Ramuan Herbal.

Berdasarkan diagram tersebut dapat di uraikan bahwa proses pembuatan ramuan herbal di mulai dari pemilihan bahan baku dan bahan penolong yang kualitasnya baik. Bahan baku ramuan herbal tersebut seperti yang telah di

Ekonomi, Sosial, dan Budaya 
kemukakan sebelumnya, diantaranya adalah : jahe, kunyit, temulawak dan sejenisnya. Sedangkan bahan penolongnya antara lain : gula jawa (merah), kayu manis, ketumbar, kedawung, biji saga dan lain - lain. Selanjutnya bahan bahan tersebut di cuci, di kupas dan di lakukan peracikan sesuai jenis ramuan herbal dengan timbangan sesuai dengan komposisi bahan. Setelah peracikan semua bahan kemudian di masak dengan air di aduk - aduk hingga mendidih sampai tercium aromanya. Kemudian ramuan di diamkan hingga dingin. Setelah itu di saring dan di kemas dalam botol ukuran 0,6 liter sambil di lakukan labelling dan penyegelan.

Kemasan dan label adalah faktor penting dalam mencapai kepercayaan konsumen. Sebelum adanya pelatihan dan pendampingan oleh tim, kemasan dan labelnya masih sangat sederhana dan tidak menarik konsumen. Namun saat ini kemasan dan label sudah lebih baik dan menarik konsumen. Berikut contoh produk ramuan herbal dan label terbarunya.

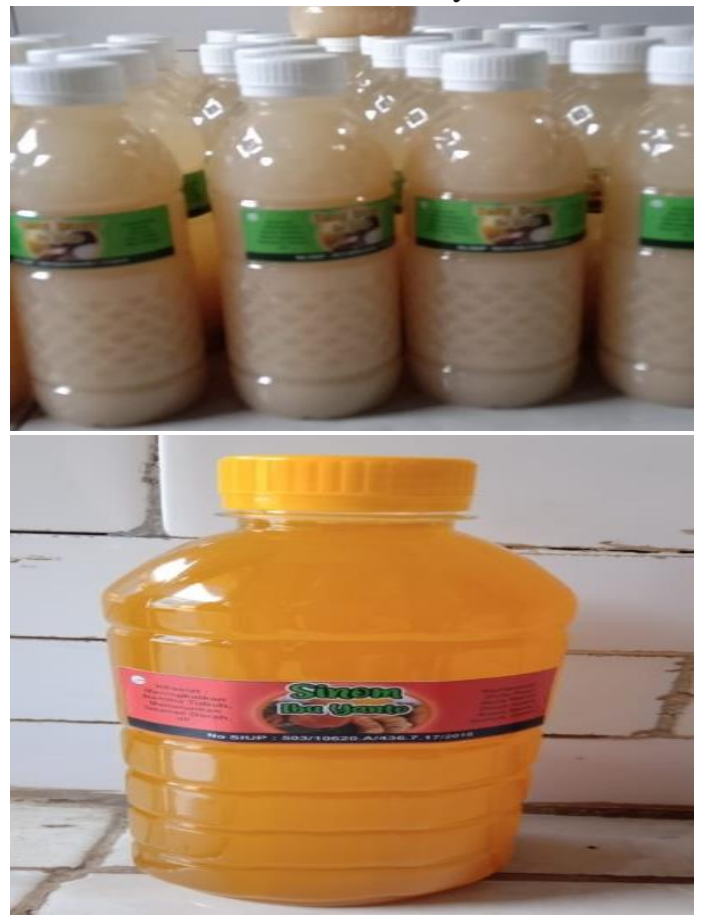

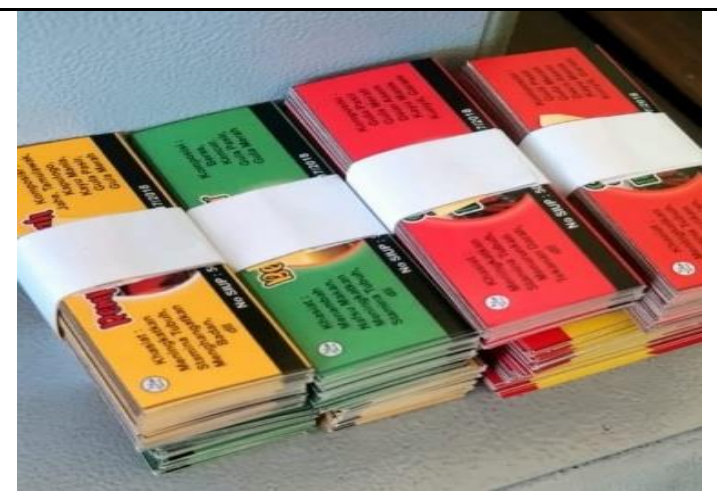

Gambar 1. Produk Ramuan Herbal dan Label.

\section{Pemasaran}

Sebelum adanya pelatihan dan pendampingan, penjualan produk hanya di lakukan dengan sistem offline yaitu di jual ke tetangga, teman, keluarga dan di titipkan di toko - toko kelontong sekitar yang mempunyai lemari pendingin namun sekarang cakupannya lebih luas karena di pasarkan melalui sistem online yaitu melalui wa, facebook, marketplace, dll. Strategi bauran promosi dapat dilakukan dengan memmanfaatkan empat metode seperti di jelaskan dalam Madura (2007:274) yaitu : iklan, penjualan perorangan(personal selling), promosi penjualan dan hubungan masyarakat (public relation). Iklan merupakan presentasi penjualan yang bersifat non personal di komunikasikan dalam bentuk media dan non media untuk mempengaruhi sebagian besar pelanggan. Personal selling adalah presentasi penjualan perorangan untuk mempengaruhi astu atau lebih pelanggan. Sedangkan promosi penjualan dapat dilakukan dengan memberikan potongan dan sampel produk (Madura, 2007:290). Selanjutnya public relation dapat di lakukan dengan mengadakan acara acara khusus seperti pameran, konferensi pers atau rilis berita (Madura, 2007:295).

\section{Administrasi dan Keuangan}

Sebagai salah satu sumberdaya yang dapat mendukung pencapaian tujuan adalah sumberdaya informasi. Sumberdaya informasi dalam suatu perusahaan dapat di hasilkan oleh

Ekonomi, Sosial, dan Budaya 
sistem informasi pemasaran, sistem informasi keuangan dan sistem informasi personalia. (Hall, 2009). Untuk itu UKM diharapkan mampu mengaplikasikan sistem keuangan yang di bantu dengan sistem pemprosesan transaksi sehingga hasil dari sistem ini dapat di gunakan untuk pengambilan keputusan. Salah satu keputusan yang harus didasarkan dengan sistem informasi keuangan adalah keputusan tentang harga pokok produk.

Di sisi lain, salah satu kelemahan usaha kecil yang lain yaitu belum adanya administrasi dan catatan dari usaha. Hal ini berdampak pada tata kelola UKM yang kurang baik, sehingga harga jual yang di tentukan belum standar dan belum bersaing. Sebagai contoh pada awal produksi, ramuan herbal di jual dengan harga sebesar Rp.6.000 per botol kemasan 0,6 liter namun selanjutnya berubah menjadi Rp.5.000 per botol kemasan 0,6 liter. Setelah di lakukan pelatihan dan pendampingan bidang keuangan, maka semua data biaya pembelian bahan dan biaya produksi lain telah di catat, sehingga harga jual dapat ddi tentukan lebih akurat yaitu sebesar Rp.5.000 per botol kemasan 0,6 liter. Metode penentuan harga pokok dapat dilakukan dengan dua cara, yaitu metode harga pokok proses dan metode harga pokok pesanan. Dalam hal ini di pilih metode penentuan harga pokok proses yaitu membebankan semua biaya produks iselama periode tertentu dan membagi sama rata kepada produk yang di hasilkan. (Mulyadi,1986;16). Metode ini di pandang sangat cocok untuk usaha kecil dan sangat sederhana.

Komponen harga pokok produksi meliputi bahan baku rempah - rempah, upah tenaga kerja langsung dan biaya overhead pabrik berupa kemasan. Sebagai contoh biaya sekali produksi pada bulan Juni 2020 jumlah biaya bahan sebesar Rp.300.000, upah tenaga kerja sebesar 4 jam @ Rp.12.500 sama dengan Rp.50.000 dan BOP berupa kemasan sebesar
Rp.100.000 sehingga total biaya produksi sebesar Rp.450.000 dengan total produk sebanyak 130 botol kemasan 0,6 liter maka harga pokok perbotol sebesar Rp.3.462. Harga jual di tentukan Rp.5.000 per botol dengan tingkat laba di tentukan sebesar $44 \%$.

Berdasarkan hasil pelatihan kegiatan administrasi dan keuangan dapat di ketahui bahwa rata - rata produksi perbulan sebanyak 2 kali produksi atau penjualan per bulan sebesar Rp.1.300.000 dengan tingkat laba kotor sebesar 44\% atau Rp. 572.000. Memang nilai produksi dan penjualan dapat dikatakan relatif masih kecil, namun setiap bulan trennya cenderung naik seiring mulai di kenalnya oleh masyarakat yang lebih luas. Berikut dokumentasi pelatihan dan pendampingan.

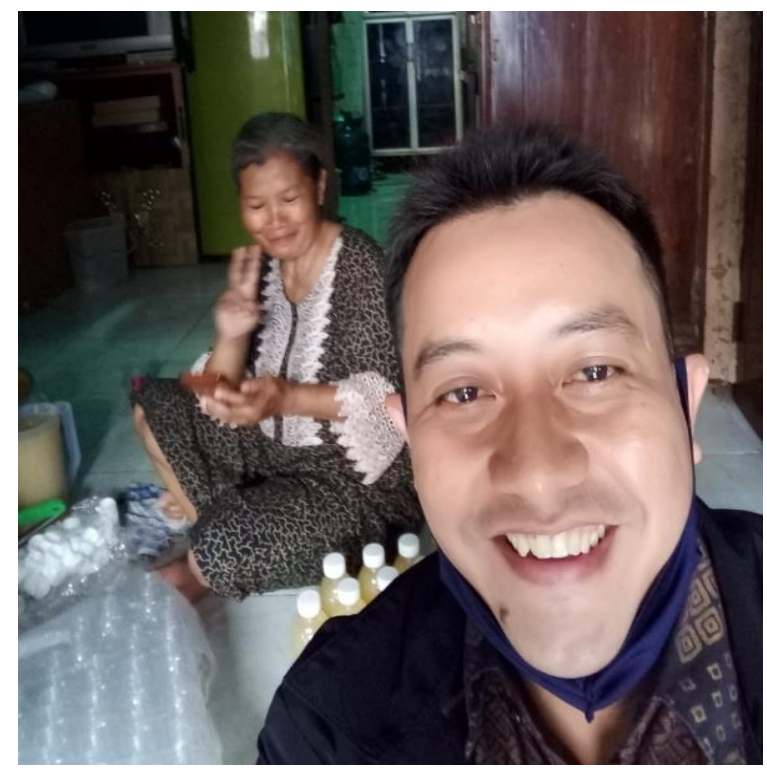

Gambar 2. Dokumentasi Peneliti dengan Mitra.

Berikut rangkuman hasil kegiatan sebelum dan setelah pengabdian.

Tabel 1. Ringkasan Hasil

Ekonomi, Sosial, dan Budaya 


\begin{tabular}{|c|c|c|}
\hline $\begin{array}{l}\mathrm{N} \\
\mathrm{O}\end{array}$ & $\begin{array}{l}\text { Kondisi } \\
\text { Sebelum } \\
\text { Kerjasama }\end{array}$ & $\begin{array}{c}\text { Kondisi Setelah } \\
\text { Kerjasama }\end{array}$ \\
\hline 1 & $\begin{array}{c}\text { Produk yang di } \\
\text { hasilkan hanya } \\
\text { satu saja yaitu } \\
\text { Sinom }\end{array}$ & $\begin{array}{c}\text { Memiliki } 3 \text { jenis } \\
\text { produk yaitu : } \\
\text { Sinom, Beras } \\
\text { Kencur dan } \\
\text { Rempah - } \\
\text { Rempah } \\
\end{array}$ \\
\hline 2 & $\begin{array}{c}\text { Belum adanya } \\
\text { pembukuan } \\
\text { administrasi } \\
\text { dan keuangan } \\
\text { sehingga harga } \\
\text { jual di tentukan } \\
\text { dengan } \\
\text { perkiraan dan } \\
\text { tidak konsisten }\end{array}$ & $\begin{array}{c}\text { Sudah } \\
\text { menggunakan } \\
\text { pembukuan } \\
\text { administrasi } \\
\text { dan keuangan } \\
\text { sehingga harga } \\
\text { jual dapat di } \\
\text { tentukan } \\
\text { dengan akurat } \\
\text { yaitu sebesar } \\
\text { Rp.5.000 per } \\
\text { botol 0,6 liter }\end{array}$ \\
\hline 3 & $\begin{array}{c}\text { Wilayah } \\
\text { pemasaran } \\
\text { hanya di } \\
\text { lakukan untuk } \\
\text { tetangga, } \\
\text { teman, keluarga } \\
\text { dan toko - toko } \\
\text { kelontong } \\
\text { sekitar rumah ( } \\
\text { offline ) }\end{array}$ & $\begin{array}{l}\text { Penjualan } \\
\text { sudah mulai } \\
\text { luas melalui } \\
\text { media WA, } \\
\text { facebook, } \\
\text { marketplace, } \\
\text { dll (online) }\end{array}$ \\
\hline 4 & $\begin{array}{c}\text { Label sangat } \\
\text { sederhana dan } \\
\text { kurang menarik }\end{array}$ & $\begin{array}{l}\text { Label lebih } \\
\text { bagus dan } \\
\text { lebih menarik }\end{array}$ \\
\hline
\end{tabular}

\section{KESIMPULAN DAN SARAN}

Berdasarkan sasaran yang di pilih dalam kegiatan pengabdian masyarakat ini terdiri dari beberapa pencapaian yaitu :

1. Dalam bidang produksi telah berkembang menjadi 3 produk yang sebelumnya hanya memproduksi sinom, kini bertambah produk beras kencur dan rempah - rempah.

2. Dalam bidang administrasi dan keuangan sudah menggunakan pembukuan sehingga dapat menentukan harga jual yang di tentukan lebih akurat.

3. Dalam bidang pemasaran sudah mulai luas karena di lakukan pemasaran selain offline juga melalui media online yaitu : wa, facebook, marketplace, dll.

4. Selain itu produk sudah menggunakan label baru yang lebih bagus dan menarik.

5. Dalam bidang umum produk telah dilakukan izin usaha sehingga produk diharapkan mendapatkan kepercayaan pasar.

\section{UCAPAN TERIMAKASIH}

Dengan selesainya kegiatan pengabdian ini, maka kami sampaikan trerimakasih yang sebesar - besarnya kepada Rektor Universitas Wijaya Putra, Dekan Fakultas Ekonomi dan Bisnis, LPPM beserta jajarannya yang telah memberikan dukungan penuh terhadap dana kegiatan ini sehingga dapat berjalan lancar. Terimaksih juga untuk Ibu Sunarti sebagai mitra yang telah memberikan kesempatam tim dalam melakukan pengabdian ini.

\section{REFERENSI}

Aniswatul,Nurul.2012.Pengolahan Sari Kedelai Sebagai Dukungan Akselerasi Peningkatan Gizi Masyarakat.Seminar Nasional Kedaulatan Pangan dan energy.Universitas Trunojoyo

Ediraras Dharma.2010.Akuntansi dan Kinerja UKM.Jurnal Ekonomi dan Bisnis.No 2.Volume 15.hal 152. Universitas Gunadarma

Eva, Dwi dan Hartini.2013.Pengaruh Jenis Kedelai dan Jumlah Air Terhadap Sifat Ekonomi, Sosial, dan Budaya 
Fisik, Organoleptik, dan Kimia Susu Kedelai. Jurnal Teknologi Industri dan Hasil Pertanian. No 02.Vol 18.Polinela

Hall, James. 2009. Sistem Informasi Akuntansi Edisi 4. Salemba Empat. Jakarta.

Madura, Jeff.2007. Introduction to Bussines. Pengantar Bisnis.Salemba Empat Edisi 4. Jakarta

Mulyadi. 1986. Akuntansi Biaya edisi 3. BPFE Yogyakarta
Sulistyo.2010.Pengembangan Usaha Kecil Menengah dengan Basis Ekonomi Kerakyatan di Kabupaten Malang.No 01.Vol 06.Jurnal Ekonomi Modernisasi.Universitas Kanjuruhan Malang

Yuliati,Erna dkk.2017.IbM Kampung Tempe Tenggilis.Jurnal Pengabdian LPPM Untag Surabaya.No 03.Vol 02.Universitas 17 Agustus 1945 Surabaya 